\title{
PENGARUH PELAYANAN PERPUSTAKAAN TERHADAP MINAT BACA SISWA DI SMP NEGERI 5 KENDARI
}

\author{
Sarliati $^{\bowtie 1}$, Arfin ${ }^{2}$, Kabiba $^{3}$ \\ Program Studi Administrasi Pendidikan, Universitas Muhammadiyah \\ Kendari123 \\ Email: sarliatianstat@gmail.com
}

\begin{abstract}
ABSTRAK
Penelitian ini bertujuan untuk mengetahui bagaimana pengaruh pelayanan perpustakaan di SMP Negeri 5 Kendari, bagaimana minat baca siswa di SMP Negeri Negeri 5 Kendari, dan apakah ada pengaruh pelayanan perpustakaan terhadap minat baca siswa di SMP Negeri 5 Kendari. Metode yang digunakan dalam penelitian ini adalah kuantitatif. Sampel dalam penelitian ini berjumlah 92 siswa. Metode pengumpulan data menggunakan angket tertutup dan dokumentasi. Hasil penelitian menunjukkan bahwa deskripsi pelayanan perpustakaan yaitu 82,25\% dikategorikan cukup baik, deskripsi minat baca siswa yaitu $63,13 \%$ dikategorikan cukup baik, dan terdapat pengaruh yang signifikan dari pelayanan perpustakaan terhadap minat baca siswa di SMP Negeri 5 Kendari. Dari uji korelasi product moment diketahui bahwa $r_{x}=0,462>r_{t} \quad=0,205$ pada taraf signifikansi $5 \%$. Hal ini menunjukkan bahwa antara kedua variabel memiliki korelasi. Hal ini dibuktikan dengan analisis regresi sederhana. Hasil perhitungan analisis regresi sederhana, diperoleh $F_{r}=24,467 d \quad F_{t_{1}}=3,95$. Jika dibandingkan maka $F_{r}>F_{t}$. Hal ini juga ditunjukkan dengan persamaan regresi sederhananya $\hat{Y}=6,460+0,689 X$.
\end{abstract}

Kata Kunci: pelayanan perpustakaan; minat baca siswa.

\begin{abstract}
This study aims to determine how the influence of library services at SMP Negeri 5 Kendari, how the reading interest of students in the Junior High School 5 Kendari, and whether there is an effect of library services on students' reading interest in the Junior High School 5 Kendari. The method used in this research is quantitative. The sample in this study amounted to 92 students. The data collection method used a closed questionnaire and documention. The results showed that the description of library services, namely $82.25 \%$, was categorized as good enough, the description of students 'reading interest, namely $63.13 \%$, was categorized as good enough, and there was a significant effect of library services on students' reading interest in SMP Negeri 5 Kendari. From the product moment correlation test, it is known that $r_{x}=0.462>r_{\text {table }}=0.205$ at the $5 \%$ significance level. This shows that the two variables have a correlation. This is evidenced by simple regression analysis. The results of the calculation of simple regression analysis, obtained $\mathrm{F}_{\text {reg }}=24.467$ and $F_{\text {table }}=3.95$. When compared, $F_{\text {reg }}>F_{\text {table. }}$ This is also shown by the simple regression equation $Y^{\wedge}=6.460+0.689 \mathrm{X}$.
\end{abstract}

Keywords: library services; student's reading interest 


\section{PENDAHULUAN}

Membaca merupakan aktivitas yang erat hubungannya dengan pendidikan, karena semakin tinggi kemampuan membaca/literasi yang dimiliki individu menunjukkan seberapa banyak wawasan dan kemampuan mencari ide maupun informasi dan ilmu pengetahuan baru yang diperoleh dari sumber manapun. Minat baca ialah keinginan yang kuat disertai usaha-usaha seseorang untuk membaca. Minat baca terkandung unsur perhatian, kemauan, dorongan dan rasa senang untuk membaca. Perhatian bisa dilihat dari perhatiannya terhadap kegiatan membaca, mempunyai kemauan yang tinggi untuk membaca, dorongan dan rasa senang yang timbul dari dalam diri maupun dari pengaruh orang lain. Semua itu merupakan aktivitas yang dilakukan dengan penuh ketekunan dan cenderung menetap.Orang yang mempunyai minat baca yang kuat akan diwujudkan dalam kesediaanya untuk mendapat bahan bacaan dan kemudiaan membacanya atas kesadaranya sendiri. Bahan bacaan tersebut yaitu surat kabar, majalah, buku pengetahuan di luar buku pelajaran, dan buku cerita, (Rahim, 2008: 28)

Dalam kegiatan belajar disekolah, minat baca siswa yang tinggi merupakan sesuatu yang diharapkan oleh semua pihak baik itu siswa sendiri, guru maupun orang tua. Namun pada kenyataannya minat baca siswa masih jauh dari apa yang diharapkan, sebab siswa hanya mencatat tugas yang diberikan oleh guru, sedangkan untuk minat baca siswa kurang, seperti buku penunjang lainnya masih tersusun rapi di rak buku. Apabila membaca sudah merupakan kebiasaan dan membudaya dalam masyarakat, maka jelas perpustakaan tidak dapat dipisahkan dari kehidupan sehari-hari dan merupakan kebutuhan pokok yang harus dipenuhi. Perpustakaan merupakan salah satu sumber belajar penting dalam proses pembelajaran. Menurut UU Perpustakaan No.43 2007 "Perpustakaan adalah institusi pengelola koleksi karya tulis, karya cetak, dan atau karya rekam secara profesional dengan sistem yang baku guna memenuhi kebutuhan pendidikan, penelitian, pelestarian, informasi dan rekreasi para siswa sebagai penggunaan perpustakaan."Ada beberapa jenis perpustakaan yang tersebar dimasyarakat, misalnya perpustakaan sekolah, perpustakaan perguruan tinggi, perpustakaan umum dan perpustakaan khusus.

Salah satu bagian yang cukup penting dalam penyelenggaraan perpustakaan sekolah adalah layanan perpustakaan. Sebagai ujung tombak jasa perpustakaan, bagian layanan berhubungan secara langsung dengan pemakai (Darmono, 2007: 164). Tujuan perpustakaan memberikan layanan khususnya kepada siswa dan umumnya masyarakat agar bahan pustaka yang telah dihimpun dan diolah sebaik-baiknya dapat dimanfaatkan oleh pembaca. Layanan perpustakaan adalah salah satu bagian yang cukup penting dalam penyelenggaraan perpustakaan sekolah.

Menurut Undang-Undang Nomor 43 tahun 2007 tentang Perpustakaan menyebutkan bahwa Perpustakaan adalah institusi pengelola koleksi karya tulis, karya cetak, dan/atau karya rekam secara profesional dengan sistem yang baku guna memenuhi kebutuhan pendidikan, penelitian, pelestarian, informasi, dan rekreasi para pemustaka. Dalam dunia pendidikan, perpustakaan sekolah sebagai salah satu sarana pendidikan penunjang kegiatan belajar siswa memegang peranan yang sangat penting dalam memacu tercapainya tujuan pendidikan di sekolah. Penjelasan Undang-undang Nomor 20 Tahun 2003, tentang Sistem Pendidikan Nasional (Sisdiknas), "Perpustakaan merupakan sarana penunjang proses balajar mengajar di sekolah". Keberadaanya sebagai salah satu komponen pendidikan merupakan suatu keharusan.

Secara umum tujuan pelayanan perpustakaan adalah agar koleksi yang disediakan oleh perpustakaan dapat dimanfaatkan semaksimal mungkin oleh siswa secara efektif dan 
efisien. Efektif dalam hal ini adalah siswa dapat memanfaatkan koleksi dan sumber informasi sehingga menghemat waktu yang mereka miliki. Efisien dalam hal ini adalah layanan perpustakaan memberikan manfaat kepada siswa, sehingga mereka merasakan menghemat biaya, karena informasi yang mereka butuhkan ada diperpustakaan sekolah (Purwani, 2014: 4). Perpustakaan bukan hanya sekedar gedung/ruangan sebagai tempat koleksi, tetapi juga sebagai sistem informasi. Sebagai sistem informasi, perpustakaan memiliki aktivitas pengumpulan, pengolahan, pengawetan, pelestarian, dan penyebaran informasi (Lasa, 2007: 18).

Berkenaan dengan pelayanan perpustakaan sekolah, maka fungsi pelayananharusdilaksanakan dengan baik. Hal ini mengingat pentingnya kedudukan perpustakaan dalam proses pendidikan. Perpustakaan menyimpan beragam koleksi yang menunjang kurikulum di lembaga pendidikan, sehingga perpustakaan diibaratkan sebagai jantung pendidikan yang memberikan kontribusi berharga dalam meningkatkan mutu pendidikan. Indikator-indikator adanya minat membaca pada seseorang adalah: 1) kebutuhan terhadapa bacaan, 2) tindakan untuk mencari bacaan. 3) rasa senang terhadap bacaan. 4) ketertarikan terhadap bacaan, 5) keinginan untuk selalu membaca, 6) tindak lanjut (menindaklanjuti apa yang sedang dibaca). Indikator siswa memiliki minat membaca tinggi, dapat diketahui dari perasaan senang terhadap bacaan, pemusatan perhatian, motivasi untuk membaca, dan usaha untuk membaca, Burs dan Lowe (Prasetyono, 2008: 59). indikator siswa memiliki minat membaca tinggi, dapat diketahui dari: (1) perasaan senang terhadap bacaan, (2) pemusatan perhatian, (3) motivasi untuk membaca, (4) usaha untuk membaca. (Muhibbin, 2010: 152),

Faktor-faktor yang mampu mempengaruhi minat baca siswa/masyarakat (Sutarno, 2006: 29). Faktor tersebut adalah: 1) rasa ingin tahu yang tinggi atas fakta, teori, prinsip, pengetahuan dan informasi, 2) keadaan lingkungan fisik yang memadai, dalam arti tersedianya bahan bacaan yang menarik, berkualitas dan beragam, 3) keadaan lingkungan sosial yang lebih kondusif, maksudnya adanya iklim yang selalu dimanfaatkan dalam waktu tertentu untuk membaca, 4) rasa haus informasi, rasa ingin tahu terutama yang aktual, 5) berprinsip hidup bahwa membaca merupakan kebutuhan rohani.

Penelitian yang relevan dengan judul penelitian pengaruh program reading morning terhadap minat baca peserta didik kelas V di MIN Sumurrejo Kota Semarang, menunjukan bahwa: dari uji korelasi product moment diketahui bahwa $r_{x}=0,757>r_{t_{1}}$ dengan taraf signifikansi $5 \%=0,312$. Hal ini menunjukkan bahwa antara kedua variabel memiliki korelasi, karena $r_{x}>r_{t_{1}}$. Dari hasil perhitungan regresi juga menunnjukkan hasil yang signifikan. Hal ini dibuktikan dari analisisregresi linier sederhana. Hasil perhitungan analisis regresi sederhana, diperoleh $F_{t_{1}}=4,098$ dan $F_{r}=50,969$. Jika dibandingkan maka harga $F_{t} \quad>F_{r}$. Hal ini juga ditunjukkan dengan persamaan garis regresi : 33,170 $+0,568 X$ dan sumbangan relatif 57,3\%. Sehingga dapat dikatakan bahwa program Reading Morning mempunyai pengaruh positif terhadap minat baca peserta didik kelas V di MIN Sumurrejo Kota Semarang, (Rahayu, 2016)

Selanjutnya Khoiriyah (2018), dengan judul penelitian pengaruh persepsi siswa mengenai pelayanan perpustakaan terhadap minat baca siswa di MI Darul Ulum Ngaliyan Semarang. Menunjukan bahwa pelayanan perpustakaan di MI Darul Ulum yaitu 101,99 atau berada pada interval 95-108 yang berarti bahwa pelayanan perpustakaan tergolong sudah cukup baik. Minat baca siswa perpustakaan di MI Darul Ulum yaitu 54,6 atau berada pada interval 50-58 yang berarti bahwa pelayanan minat baca siswa tergolong cukup baik. Terdapat pengaruh yang signifikan dari persepsi siswa mengenai pelayanan perpustakaan terhadapminat baca siswa di MI Darul Ulum Ngaliyan Semarang. 
SMP Negeri 5 Kendari merupakan salah satu lembaga pendidikan yang bertaraf Internasional dan sebagai sekolah Adiwiyata. Berdasarkan hasil pra survei yang telah dilakukan salah satu permasalahan yang mempengaruhi siswa jarang masuk perpustakaan adalah kurangnya minat baca. Hal menjadi tugas pengelola perpustakaan untuk meningkatkan pelayanan perpustakaan dengan menarik simpati para siswa agar lebih termotivasi untuk membaca di perpustakaan. Salah satu contoh pelayanan perpustakaan seperti menata dengan rapi buku dan tata letak ruang perpustakaan serta mengupayakan untuk selalu berkoordinasi dengan pihak sekolah agar bisa menambahkan koleksi buku yang ada di perpustakaan, selain itu penjaga perpustakaan juga lebih sering meyakinkan atau memberikan informasi kepada siswa betapa pentingnya membaca karena melalui membaca siswa bisa mendapatkan ilmu pengetahuan yang luas, maka siswa akan termotivasi untuk membaca di lingkungan perpustakaan sekolah tanpa harus mengharapkan materi pendidikan dari guru semata. Adapun tujuan dari penelitian adalah untuk mengetahui pelayanan perpustakaan di SMP Negeri 5 Kendari, bagaimana minat baca siswa di SMP Negeri 5 Kendari, dan apakah ada pengaruh pelayanan perpustakaan terhadap minat baca siswa di SMP Negeri 5 Kendari.

\section{METODE}

Penelitian ini menggunakan metode kuantitatif yaitu suatu proses menemukan pengetahuan yang menggunakan data berupa angka sebagai alat menemukan keterangan mengenai apa yang ingin kita ketahui. Pendekatan ini dikatakan kuantitatif karena data penelitian berupa angka-angka dan analisis menggunakan statistik. Variabel yang digunakan adalah variabel bebas atau variabel $X$ (Pelayanan perpustakaan) dan variabel terikat atau variabel Y (Minat baca siswa).

Populasi dalam jumlah besar akan mempersulit peneliti untuk melakukan penelitian, sehingga diperlukan sampel. Sampel adalah sebagian dari populasi terjangkau yang memiliki sifat yang sama dengan populasi (Sudjana, 2004: 85). Adapun populasi dalam penelitian ini adalah seluruh peserta didik di SMP Negeri 5 Kendari yang berjumlah 1.080 peserta didik. Sementara sampel yang harus di ambil berjumlah 92 responden berdasarkan rumus Slovin. Penentuan sampel penelitian ini menggunakan teknik random sampling.

Penelitian ini menggunakan instrumen berupa angket tertutup yang disertai dengan alternatif jawaban, sehingga responden tinggal memilih jawaban yang paling sesuai. Dalam pengukuran setiap variabel ini, skala yang digunakan adalah skala bertingkat (rating scale). Angket disediakan dengan 4 alternatif jawaban, sehingga responden tinggal memberi tanda $(\times)$ pada jawaban yang tersedia. Pengumpulan data dilakukan melalui tindakan observasi, pengisian angket, dan dokumentasi. Fungsi observasi adalah untuk mengamati secara langsung pelayanan perpustakaan terhadap minat baca siswa SMP Negeri 5 Kendari. Sementara itu, pengisian angket digunakan untuk memperoleh data tentang pelayanan perpustakaan terhadap minat baca siswa di SMP Negeri 5 Kendari. Dokumentasi digunakan untuk mengumpulkan data-data dengan melihat bahan-bahan dokumentasi yang ada di SMP Negeri 5 Kendari.

Teknis analisis data yang digunakan adalah teknik analisis statistik deskriptif dan teknik analisis statistik inferesial yang bertujuan untuk mengkaji variabel penelitian.

\section{HASIL DAN PEMBAHASAN}

\section{Hasil Penelitian}

Penelitian ini melakukan analisis statistik deskriptif dan analisis statistik inferensial tentang pengaruh pelayanan perpustakaan terhadap minat baca siswa di SMP Negeri 5 Kendari. 


\section{Deskripsi Data Pelayanan Perpustakaan SMP Negeri 5 Kendari}

Deskripsi data pelayanan perpustakaan diperoleh untuk mengetahui nilai kuantitatif pelayanan perpustakaan yang dilakukan dengan cara menggunakan total jawaban angket sebanyak 19 item pernyataan kepada 92 responden.Dari perhitungan tersebut diketahui bahwa nilai mean dari pelayanan perpustakaan sebesar 82,25 atau berada pada interval 74 - 90 yang berarti bahwa pelayanan perpustakaan di SMP Negeri 5 Kendari dalam kategori cukup baik.

\section{Deskripsi Data Minat Baca Siswa SMP Negeri 5 Kendari}

Deskripsi data minat baca siswa diperoleh untuk mengetahui nilai kuantitatif minat baca siswa yang dilakukan dengan cara menggunakan total jawaban angket sebanyak 18 item pernyataan kepada 92 responden. Dari perhitungan tersebut diketahui bahwa nilai mean dari minat baca siswa sebesar 63,13atau berada pada interval 56 - 69 yang berarti bahwa minat baca siswa di SMP Negeri 5 Kendari dalam kategori cukup baik.

\section{Pengaruh Pelayanan Perpustakaan terhadap Minat Baca Siswa SMP Negeri 5 Kendari}

Uji normalitas bertujuan untuk menguji apakah dalam model regresi, variabel pengganggu atau residual memiliki distribusi normal. Suatu model regresi yang baik adalah dimana datanya berdistribusi normal. Distribusi normal dalam penelitian ini penulis menggunakan analisis statistik non-parametrik Kolmogorov Smirnov.

Tabel 1. Hasil Pengujian Normalitas Kolmogorov Smirnov

One-Sample Kolmogorov-Smirnov Test

\begin{tabular}{|ll|r|}
\hline & & $\begin{array}{c}\text { Unstandardized } \\
\text { Residual }\end{array}$ \\
\hline & Mean & 92 \\
Normal Parameters ${ }^{\mathrm{a}, \mathrm{b}}$ & Std. Deviation &, 0000000 \\
Most Extreme & Absolute & 11,96685913 \\
Differences & Positive &, 095 \\
Kolmogorov-Smirnov Z & Negative &, 061 \\
Asymp. Sig. (2-tailed) &,- 095 \\
Asy &, 907 \\
\hline
\end{tabular}

a. Test distribution is Normal.

b. Calculated from data.

Berdasarkan hasil analisis di atas, diketahui bahwa nilai Asymp.Sig. (2 tailed) sebesar 0,383 lebih besar dari 0,05. Sesuai dengan dasar pengambilan keputusan dalam uji normalitas kolmogorov smirnov, dapat dikatakan bahwa data berdistribusi normal. Dengan demikian, asumsi normalitas dalam model regresi sudah terpenuhi.

\section{Analisis Uji Hipotesis}

Pengujian ini dimaksudkan untuk mengetahui sejauh mana pengaruh antara pelayanan perpustakaan terhadap minat baca siswa di SMP Negeri 5 Kendari. Dari hasil uji korelasi product moment diketahui bahwa $r_{x}=0,462$ berarti signifikan artinya hipotesis diterima, $r_{x}=0,462>r_{t} \quad=0,205$ pada taraf signifikansi $5 \%$.

Berdasarkan uji koefisien yang ditemukan sebesar 0,462 termasuk dalam kategori sedang karena berada pada rentang 0,40 - 0,70. Sehingga dapat dinyatakan bahwa korelasi antara variabel $\mathrm{X}$ dan variabel $\mathrm{Y}$ adalah variabel yang tergolong sedang. Jadi terdapat hubungan yang sedang antara pelayanan perpustakaan dan minat baca siswa di SMP Negeri 5 Kendari. Sedangkan arah hubungan adalah positif karena nilai r positif, sehingga semakin 
baik pelayanan perpustakaan di SMP 5 Kendari maka semakin baik pula tingkat minat membaca siswa. Selanjutnya untuk menyatakan besar kecilnya sumbangan variabel $\mathrm{X}$ terhadap $\mathrm{Y}$ dapat ditentukan dengan rumus koefisien determinan variabel $\mathrm{X}$ terhadap $\mathrm{Y}$, maka dilakukan proses perhitungan sebagai berikut:

$$
\begin{aligned}
K & =(r)^{2} \times 100 \% \\
& =(0,462)^{2} \times 100 \% \\
& =0,213 \times 100 \% \\
& =21,3 \%
\end{aligned}
$$

Jadi diketahui variabel penentu antara variabel X dan variabel $Y$ sebesar 21,3\% sedangkan sisanya 78,7\% merupakan variabel lain yang belum diteliti penulis.

Diketahui nilai b sebesar 0,689 dan nilai a sebesar 6,460 maka persamaan garis regresinya adalah $\hat{Y}=6,460+0,689 \mathrm{X}$. Dalam penelitian ini menggunakan taraf signifikansi $5 \%$ dengan derajat kebebasan pembilang 1 dan penyebut 90 , maka diperoleh $F_{t} \quad 5 \%=$ 3,95 dan hasil perhitungan diperoleh $F_{h i 1}=24,467$, karena $F_{t}=24,467>F_{t}=$ 3,95, nilai ini digunakan untuk menguji keberartian regresi dari variabel pelayanan perpustakaan $(\mathrm{X})$ maka dapat disimpulkan bahwa pelayanan perpustakaan berpengaruh signifikan terhadap minat baca siswa di SMP Negeri 5 Kendari. Dalam penelitian ini menggunakan taraf signifikansi 5\% dengan derajat kebebasan pembilang 1 dan penyebut 91, maka diperoleh $\tau_{t} \quad 5 \%=1,662$ dan hasil perhitungan diperoleh $\tau_{\text {hit }}=4,941$, karena $t_{\text {hĩi }} \quad=4,941>t_{t} \quad=1,662$ berarti signifikan artinya hipotesis diterima.

\section{Pembahasan}

Hasil pengujian secara statistik deskriptif yang menunjukkan mean dari pelayanan perpustakaan SMP Negeri 5 Kendari sebesar 82,25 atau berada pada interval 74 - 90 yang berarti bahwa pelayanan perpustakaan SMP Negeri 5 Kendari tergolong cukup baik. Dalam hal ini perpustakaan dapat menjalankan fungsinya dengan cukup baik, seperti sistem pelayanan yang diberikan pustakawan perpustakaan SMP Negeri 5 Kendari kepada siswa, guru, dan karyawan adalah sistem pelayanan terbuka. Artinya memberi kesempatan seluasluasnya kepada seluruh siswa, guru, dan karyawan SMP Negeri 5 Kendari untuk menggunakan semua fasilitas yang tersedia diperpustakaan. Selain pelayanan sirkulasi, perpustakaan SMP Negeri 5 Kendari juga memberikan pelayanan referensi, didalam pelayanan tersebut pustakawan memberikan informasi kepada siswa yang membutuhkan bantuan mencari buku dan memberikan bimbingan belajar bagi siswa yang kesulitan dalam membaca atau belajar. meyediakan koleksi buku yang berkualitas dansesuai kebutuhan siswa, dapat memberikan kenyamanan ruangan, serta kinerja pustakawan yang baik dalam memberikan pelayanan kepada siswa (wawancara dengan Kepala perpustakaan, Ibu Sitti Halia, S.Pd di ruang perpustakaan pada tanggal 23 Juni 2020).

Hasil pengujian secara statistik deskriptif yang menunjukkan mean dari minat baca siwa di perpustakaan SMP Negeri 5 Kendari sebesar 63,13 atau berada pada interval 56 -69 yang berarti bahwa minat baca siswa SMP Negeri 5 Kendari tergolong cukup baik, yang ditunjukkan dengan kebutuhan terhadap bacaan, tindakan untuk mencari bacaan, perasaan senang terhadap bacaan, ketertarikan terhadap bacaan, dan keinginan untuk selalu membaca.

Dalam analisis korelasi product moment pearson menghasilkan $r_{x}=0,462>$ $r_{\mathrm{t} .} \quad{ }_{l}=0,205$ pada taraf signifikansi $5 \%$ yang berarti signifikan. Berdasarkan interpretasi maka koefisien yang ditemukan sebesar 0,462 termasuk dalam kategori sedang karena berada pada rentang $0,40-0,70$. Jadi terdapat hubungan yang sedang antara pelayanan perpustakaan dan minat baca siswa di SMP Negeri 5 Kendari. Sedangkan arah hubungan 
adalah positif karena nilai $\mathrm{r}$ positif, sehingga semakin baik pelayanan perpustakaan di SMP Negeri 5 Kendari maka semakin baik pula tingkat minat membaca siswa.

Pada analisis regresi sederhana didapatkan jawaban persamaan regresi sederhananya $\hat{Y}=6,460+0,689 \mathrm{X}$ atau dengan kata lain apabila frekuensi "pengaruh pelayanan perpustakaan (Variabel X) bertambah satu satuan, maka "minat baca siswa (Variabel Y) akan bertambah 0,689. Dapat disimpulkan bahwa semakin tinggi atau semakin baik pelayanan perpustakaan maka semakin tinggi pula minat baca siswa. Sementara pada perhitungan secara keseluruhan (simultan) pelayanan perpustakaan mempunyai pengaruh terhadap minat baca siswa karena nilai dari hasil uji $F_{h i t}=24,467>F_{t_{i}}=3,95$ pada taraf signifikansi 5\%. Dengan demikian dapat diketahui bahwa ada pengaruh pelayanan perpustakaan terhadap minat baca siswa sebesar 24,467.

Berdasarkan hasil analisis ini, sesuai dengan teori yang menyebutkan bahwa pelayanan menjadi tolak ukur bagi keberhasilan kerja suatu perusahaan/instansi/organisasi yang berorientasi kepada kepuasan pelanggan dengan cara memberikan jasanya kepada pelanggan/penggunanya (Nina, 2013: 18). Apabila perpustakaan meningkatkan pelayanan di dalam perpustakaan, salah satunya dengan adanya pustakawan atau tenaga perpustakaan yang memiliki pengetahuan dan keterampilan bidang kepustakawanan yang memadai. Maka pelayanan perpustakaan berjalan dengan baik, sehingga citra perpustakaan dapat dijaga dengan baik dimata pengunjung, dan pengunjung senang berkunjung ke perpustakaan dan minat baca akan tumbuh dan berkembang dengan sendirinya.

\section{SIMPULAN}

Berdasarkan hasil penelitian pengaruh pelayanan perpustakaan terhadap minat baca siswa di SMP 5 Kendari dapat menjelaskan bahwa: pengaruh pelayanan perpustakaan terhadap minat baca siswa di SMP Negeri 5 Kendari dapat dijelaskan oleh uji korelasi product moment diketahui bahwa $r_{x}=0,462>r_{t} \quad=0,205$ pada taraf signifikansi $5 \%$. Hal ini menunjukkan bahwa antara kedua variabel memiliki korelasi. Selanjutnya akan dibuktikan dengan analisis regresi sederhana dengan melihat nilai $F$ yaitu $F_{r \epsilon}=24,467>$ $F_{\mathrm{t}} \quad=3,95$. Sehingga dapat menjelaskan bahwa ada pengaruh yang signifikan antara pelayanan perpustakaan terhadap minat baca siswa. Besarnya pengaruh tersebutakan digambarkan dengan persamaan regresi sederhana yang diperoleh yaitu $: \bar{Y}=6,460+$ $0,689 X$ yang menjelaskan bahwa jika variabel $X$ pelayanan perpustakaan bernilai 1 satuan akan memberikan pengaruh sebesar 7,149 nilai variabel $Y$ minat baca maka dapat disimpulkan bahwa semakin baik pelayanan perspustakaan SMP Negeri 5 Kendari semakin meningkatkan minat baca siswa.

\section{DAFTAR PUSTAKA}

Khoiriyah, Siti. 2018. Pengaruh Persepsi Siswa Mengenai Pelayanan Perpustakaan Terhadap Minat Baca Siswa Di MI Darul Ulum Ngaliyan Semarang. [Diakses Pada Tanggal 27 September 2019 Pukul 14.45].

Lasa Hs. 2007. Manajemen Perpustakaan Sekolah. Yogyakarta: PinusBook Publisher.

Muhibbin, Syah. 2010. Psikologi Pendidikan dengan Pendekatan Baru. Bandung: Remaja Rosdakarya.

Nina, Rahmayanty. 2013. Manajemen Pelayanan Prima. Yogyakarta: Graha Ilmu.

Observasi dan wawancara dengan Kepala perpustakaan, ibu Sitti Halia diruang gedung perpustakaan pada tanggal 13 Maret 2020. 
Purwani, Istiana. 2014. Layanan Perpustakaan. Yogyakarta: Penerbit Ombak.

Prasetyono, Dwi Sunar. 2008. Rahasia Mengajar GemarMembaca Pada Anak Sejak Dini. Jogjakarta: Think.

Sutarno NS. 2006. Perpustakaan dan Masyarakat. Jakarta: Anggota IKAPI.

Sudjana, Nana. 2004. Penelitian dan Penilaian Pendidikan. Bandung: Sinar Baru Algensindo. Undang-Undang Nomor 43 tahun 2007. Tentang Perpustakaan Sekolah. Jakarta: Perpustakaan Nasional.

Undang-undang Nomor 20 Tahun 2003. tentang Sistem Pendidikan Nasional (Sisdiknas)

Rahim, Farida. 2008. Pengajaran Membaca di Sekolah Dasar.Jakarta: Bumi Aksara.

Rahayu, Ratna Surya. 2016. Pengaruh Program Reading Morning Terhadap Minat Baca Peserta Didik Kelas V di MIN Sumurrejo Kota Semarang. Semarang: Fakultas Ilmu Tarbiyah dan Keguruan UIN Walisongo. 